This is the final peer-reviewed accepted manuscript of:

The Social Roots of the Gender Gap in Political Participation: The Role of

Situational and Cultural Constraints in Italy in Social Politics (2017), 24, 3 p.221-247

Laura Sartori, Dario Tuorto, Rossella Ghigi

The final published version is available online at: https://doi.org/10.1093/sp/ixx008

Rights / License:

The terms and conditions for the reuse of this version of the manuscript are specified in the publishing policy. For all terms of use and more information see the publisher's website.

This item was downloaded from IRIS Università di Bologna (https://cris.unibo.it/)

When citing, please refer to the published version. 


\section{The Social Roots of the Gender Gap in Political Participation: The Role of Situational and Cultural Constraints in Italy}

\section{Laura Sartori ${ }^{1 * *}$, Dario Tuorto ${ }^{2}$, and Rossella Ghigi ${ }^{2}$}

The paper takes an innovative approach to the study of political participation by combining it with a gender studies perspective, investigating the role of structural and situational constraints in the highly gendered context of Italy. Such constraints channel women's time away from politics, but neither do they account for the whole difference, which calls for an additional explanation, identified with specific cultural constraints. As expected, there is a remarkable gap between women and men in traditional time-consuming political activities and situational constraints have a negative impact on women's participation, and surprisingly also have a negative effect on men's involvement.

\section{Introduction}

Gender inequalities in political participation are persistent, even though gender gaps in political power, resources, representation, and participation have been significantly reduced in many industrialized countries over the past fifty years (Hayes and Bean 1993; Paxton, Kunovich, and Hughes 2007). Nonetheless, it is internationally acknowledged that women are still far from matching men's level of involvement in political actions, influence, and representation (Burns, Schlozman, and Verba 1997; Burns 2007; Morales 2009; Norris 2002; Schlozman, Burns, and Verba 1999; Sundström and Stockemer 2015) nor are they comparable in terms of political knowledge, information, and interest (Burns, Schlozman, and Verba 2001; Coffé 2013; Dow 2009; for methodological issues, see Fraile 2014).

While acknowledging the richness of international studies on this topic, we would like to focus on the Italian case for several reasons. Indeed, Italy is an

\footnotetext{
${ }^{1}$ Dipartimento di Scienze Politiche e Sociali, University of Bologna, Via dei Bersaglieri 6, Bologna, Italy

${ }^{2}$ Dipartimento di Scienze dell'Educazione, University of Bologna, Via Filippo Re 6, Bologna, Italy
} 
interesting case insofar as it is a highly gendered context where women appear particularly dedicated to the domestic sphere: irrespective of their employment status, income, or education, they spend much more time than men doing household-related activities (Dotti and Maria 2012), which reflects the persistence of traditional norms of gender-appropriate behavior (Anxo et al. 2011; Craig and Mullan 2010; Mencarini and Tanturri 2004). Also, Italian women participate less in the labor force compared to the European average (Eurostat 2016) due to a rigid labor market (Naldini and Saraceno 2011; Solera 2009) and a conservative welfare state that does not invest in social pol-icies such as childcare (Ferrera 1996). The longlasting legacy of the Catholic tradition ${ }^{1}$ adds a further contribution to the Italian context where the process of political socialization and the social construction of gender within the do-main of politics still negatively influence women's perception as valuable actors (Cartocci 2011). Additionally, Italian women are less likely to engage with voluntary organizations (Quaranta 2016a), run for public office, or to be elected as MPs (Eige 2016; Morales 2009). Furthermore, the availability of a good and underutilized dataset reinforces the interest and meaningfulness of the Italian case.

We aim to explore the gender gap in political participation linked to women's exclusion from the public sphere. Interestingly, there is a lack of research on forms of women's political participation other than electoral turnout, a topic studied intensively since the post Second World War period (Corbetta and Cavazza 2008; Dogan 1967). Even recently, most Italian studies tend to focus solely on women's traditional and institutional participation (party membership, party delegates, gender stereotypes in political representation and leadership; Bordandini, Di Virgilio, and Mulé 2011; Brunelli 2006; Molfino 2006; Sarlo and Zajczyk 2012) or look at contemporary movements and associations (Bonomi Romagnoli 2014; Magaraggia and Vingelli 2015). A growing literature and empirical research is now devoted to the gender gap in social and volunteer participation [Helms and McKenzie (2014) on Germany; Piper and Schnepf (2008) on the UK; Quaranta (2016a) on Italy], but in the last 20 years political participation has been understudied within gender research, especially when compared with other forms of involvement in daily life.

This article aims to build upon the literature of political participation by integrating a gender studies perspective on attitudes and behaviors towards politics, with a focus on the Italian case. Drawing upon a wide range of international and comparative references (Fraile 2014; Gallego 2008; Jennings 1983; Jennings and Farah 1990; Stolle and Hooge 2011; Welch 1977; Vassallo 2006; Verge Mestre and Tormos Marin 2012) this article is divided into four sections. In the "Overview of Past Research" section, we develop a rich and multifaceted theoretical framework that sustains our core hypothesis, which is further detailed in the "Hypotheses, Data and Methods" section along with a description of our data and methods. An illustrative analysis of specific types 
of engagement also allows us to investigate whether women prefer nonconventional to traditional forms of participation and, in order to capture the specificity of politics, we use engagement in social and leisure activities as a benchmark. The section "It's Not Just a Matter of Time" examines and expounds upon the extent to which situational variables (transitions to union formation and parenthood, and the distribution of domestic work) account for gender differences, while the "Discussion" section discusses empirical evidence from a gendered perspective, highlighting the relevance of cultural factors that specifically limit women's political participation compared to other forms of public and social activities.

\section{Overview of Past Research}

\section{Explaining Women's Political Participation}

A number of explanations have been advanced to address the gender dimension of political participation, since it is the outcome of convergent multiple gendered dynamics such as political socialization and attitudes, resources and life-course experiences (Bernstein 2005; Clark and Clark 1986; Conway, Ahern, and Steuernagel 2004; Fox and Lawless 2014; Fridkin and Kenney 2007; Stake 2007). In a classic study, political scientist Susan Welch (1977) identified three sets of explanatory factors for gendered paths in political par-ticipation. Women do not participate as much as men because of their struc-tural characteristics (including education, employment, occupation, and income, but also legal and political structures, such as discrimination and in-stitutional barriers), their situation (including marital status and family ar-rangements, such as being a wife, mother, single parent), and their socialization (including childhood and adult political socialization, but also socialization outcomes such as dependence or emphasis on personal rela-tions). There is a causal link between these three sets of explanations that is worth noting. While situational factors look at current characteristics and so-cial roles of individuals, structural features stretch back into individual histories encompassing outcomes that refer to economic (labor market) and social (school, family) institutions (Jennings 1983). The socialization hypothesis pushes back even further the roots of different participative roles that might be resistant to intervening structural (education) and situational (familiar transitions and arrangements) factors. Moreover, social organizations such as the family, the labor market and public engagement rely on prevalent male/ female relationships and lead to distinct lists of priorities or duties for women that support or discourage political participation (Welch 1977).

In their comparative study on the gender gap along several dimensions of public life (from education to social participation) in eight post-industrial Western nations, including Italy, Jennings and Farah (1990) highlighted a complex dynamic comprising socialization, situational constraints, and 
structural disadvantages that all work together. It did not prevent Italian women from developing similar political preferences and evaluations to men's, but — comparatively — this dynamic affected those individual resources, such as their self-esteem, motivations, skills, and opportunities, which are essential to a full, active, and informed participation. As a result, some societies reflect more traditionalist attitudes towards women's roles (e.g. preferences for men in public office, political recruitment, or the labor market) as in the cases of Italy and West Germany in the post Second World War period (Kolinsky 1989; Sani 1980).

Interestingly, this literature suggests the need not only to assess the gender gap in political participation (that is to say, measuring the difference between men and women in various forms of political engagement), but also to subsume a gender perspective. In this way, it is possible to see to what extent politics and femininity are constructed as mutually exclusive categories: historically, matters pertaining to politics were addressed to adult, heterosex-ual, free male citizens while women were excluded from political processes and institutions across countries and ages until the twentieth century. Conversely, the social construction of femininity as well as the sexual division of labor implied the notion of domesticity and the exclusion from public space and sites of production, relegating women to the domain of intimate relationships: the female subject was constructed as not involved in political is-sues until the second-wave feminist movement challenged the very notion of politics (Cavarero 2002; Fraser 1997). This perspective has been recently dismissed, but we believe it is still worth introducing a gender perspective to the study of political participation. We will discuss our findings in the light of these insights in the "Discussion" section.

\section{Types of Engagement and Political Participation}

Research has offered many helpful typologies of political participation, besides electoral behavior. Some authors introduced a distinction between conventional and unconventional participation when considering activities within, outside, or against political parties and institutional involvement (Barnes and Kaase 1979). Others labeled the propensity to inquiry and political discussion as a form of invisible or latent participation (Ekman and Amna 2012) in con-trast to visible activities such as donating money or attending political meet-ings. Acquiring knowledge and skills that help tackle the complexity of politics through informed opinion is known as cognitive mobilization (Dalton 1984), as part of a more general process of mobilization that refers to a party's internal or external actions in the collective sphere with the goal of changing the existing distribution of power (Nedelman 1987). Recent forms of political consumerism and alternative ways of protest called for the distinction between representative and nonrepresentative activities (Teorell, Torcal, and Montero 2007). Despite the plurality of available typologies, the relevant fact for our 
purposes is that women and men do appear to engage differently in such a variety of political activities.

Some authors suggest that women usually address their attention toward small-scale organizations and prefer less traditional actions that can be incorporated into daily life, such as fund-raising, petitions, critical consumerism (Stolle, Hooghe, and Micheletti 2005), charity work, and social caring activities (Burns, Schlozman, and Verba 2001). Recently, the Internet has offered opportunities for women to create personalized forms of participation through online communities and social media practices, such as social networking (Bode 2016) and the do-it-yourself (DIY) culture (Harris 2008), en-abling them to overcome their feeling of inadequacy within the boundaries of conventional politics.

Institutional participation diverges from more unconventional forms of civic activism in the material or symbolic resources they require from participants. Women find it challenging to engage in highly skilled, expensive, and time-intensive forms of institutionalized politics (within political parties and more structured organizations: Burns 2007; Coffé and Bolzendahl 2010; Paxton, Kunovich and Hughes 2007). Thus, a differentiated access to available resources leads men and women towards alternative forms of engagement, some of which are more accessible and attractive for women (Lister 2003; Lovenduski 1998).

\section{Structural and Situational Constraints on Political Participation}

The description of structural and situational factors sets the context for our empirical analysis. Individual characteristics and socio-economic resources (what we call structural factors) are crucial assets and their combinations with gender have a complex and multifaceted impact on political participation. Education is key worldwide: it provides and consolidates those cognitive skills necessary for acquiring useful information to evaluate leadership and policy options. Higher levels of education push women (especially among younger generations) to actively engage in organizations where political matters are discussed, as a first step towards formal and informal efforts in political mobilization (Burns, Schlozman, and Verba 2001). Interestingly, holding a university degree significantly increases the likelihood of party activism for women, whereas it is appears insignificant for men (Coffé and Bolzendahl 2010). Moreover, employment is positively related to political participation and information to a point that counterbalances-or at least reduces-the gender gap in participatory practices (Schlozman, Burns, and Verba 1994). Yet, contrary to men who share the same occupational position, women's political participation declines as office hours increase, due to their greater involvement in domestic work. Income sustains participation through individual donations to political issues and requests to become an economic supporter of an electoral campaign. In general, workers earn more money and have more 
opportunities to exercise participation-enhancing communication and organizational skills, which are crucial for political engagement (Schlozman, Burns, and Verba 1999). Women also demonstrate lower commitment to group activities that are supposed to enhance those targeted skills—a complex mix of verbal ability, knowledge about government, education, time, money, perceived efficacy among others-needed for civic and political participation (Verba, Burns, and Schlozman 1997). However, when women are educated, employed, with stronger ties outside the household and a good stock of social capital, they are more likely to be politically active (Chibber 2002; Lowndes 2004).

Attitudes and practices are not only shaped by structural factors, but also by life-course experiences, encompassed by what we call situational factors. Transitions to union formation and parenthood may cause transformations in time availability and personal priorities that affect political participation. Married people are generally mobilized towards traditional types of participation such as voting (Kingston and Finkel 1987). Once married, women's free time devoted to leisure activities declines to a greater extent than men's, and their amount of time spent on housework increases, whereas men's contribution to domestic duties often declines (Sayer 2005). National differences also matter. Marriage has a minor negative effect on voluntary associational membership among US women, while there is a strong increase in membership for men (Rotolo 2000). British women are found to retreat from political participation more than men (Parry, Moyser, and Day 1992) while no significant effect is found in the American case (Burns, Schlozman and Verba 2001; Morales 2009). In southern European countries in particular, marital status affects men and women differently, and women tend to refrain from public affairs (Morales 2009) whether these are new or traditional forms of political membership (Teorell, Torcal, and Montero 2007).

As for marriage, marital break-up also has an impact on public engagement, since it may split the couple's joint social networks and resources (Amato 2000; Kalmijn and van Groeno 2005). At least in the short run, the new lifestyles of divorcees may push them away from public issues (Stoker and Jennings 1995) just as widowhood negatively impacts voter turnout (Hobbs, Christakis, and Fowler 2014). For example, Swiss women retreat from more traditional types of political participation, such as voting, while no negative effect is found in men (Voorpostel and Coffé 2012). In general, divorce and separation have a stronger negative effect on women in terms of resources important to political commitment, but in some cases may enable women to counter traditional gender pressures resulting in a positive impact on political participation.

Transition to parenthood also has implications for politics since children may be considered either as constraints or connections (Gallagher and Gerstel 2001). As constraints, children may lead to a restriction of financial resources because the overall demand for domestic and care work increases (Mattingly 
and Bianchi 2003), leaving less free time for community networking and network maintenance (Munch, McPherson, and Smith-Loving 1997). As connectors, children can strengthen parents' ties to local community, neighbors, and family: parents of school-aged children are more likely to be active in school politics (Voorpostel and Coffé 2012), in the local community, and in other children's issues (Burns, Schlozman, and Verba 1997; Jennings 1979; Sapiro 1982; Smith 1994; Wilson and Musick 1997). Children can also act as a bridging resource, allowing parents to interact with more and diverse people and institutions (Moore 1990; Nomaguchi and Milkie 2003). In general, having children not only influences political attitudes, but it can also positively support women's political participation.

Overall, marriage, divorce, and having children are life-experiences that have an effect on the resources needed for proactive styles of participation for both women and men (Quaranta 2016b). Unlike individual characteristics and socio-economic resources, their impact as situational constraints is not always straightforward but depends on the prevalent cultural model in a given society. The degree to which these life experiences affect political participation for women and men varies according to the social organization of specific domains such as family, labor market, and public life. While evidence on the association between political participation and family structure is widely available, its relation with allocation of time to domestic work is less explored, with few exceptions (Romano and Ranaldi 2008; Romano, Mencarini, and Freguja 2012). From this point of view, one of the advantages of our analysis is that it assesses the impact of a (gendered) lack of free time on political participation.

\section{Cultural Constraints on Political Participation}

Research across multiple countries suggests that men are still encouraged or even expected to know about and/or to participate in politics more than women. The persistent idea that the public sphere-and politics in particular-is not suitable for women in sex-role socialization results in their lower political participation, in terms of interest, knowledge, and other activities. As a matter of fact, with all the meanings involved in terms of entitlement to public space, leadership, and self-reliance, early socialization affects political interest, information, and efficacy over the entire life course, shaping participation independently from other characteristics (Burns 2007; Fridkin and Kenney 2007; Lovenduski 2005; Rapoport 1981; Ridgeway 2011). This also explains why men do not generally fear resource-demanding modes of political participation (Norris 2002) while women show higher levels of involvement and participation when family-related issues are at stake in the political arena. Recent studies showed that women are more likely to have knowledge on specific policy areas that directly affect their daily lives, such as education, health care, political rights, and the functioning of social services (Fraile 2014). 
The gendered process of socialization has led women to be more interested in the local, domestic, and private dimensions (especially when "political interest" is framed in the traditional way, Coffé 2013), to develop a lower sense of self-efficacy in politics (Pateman 1970; Pizzorno 1993), and to feel uncomfortable with traditional forms of political activity (Lister 2003) or to avoid political conflict. Furthermore, gender differences in political behaviors and attitudes appear to be specific to politics rather than simple extensions of personal attributes (Verba, Burns, and Schlozman 1997). Coffé (2013) found evidence of socialized gendered attitudes towards conflict: especially in nonpartisan or non-conventional politics, women tend to avoid political conflict and, thus, political engagement. Overall, it is the way both the political domain and gender differences are constructed that has kept women away from politics: explicitly discriminatory discourses, closed political structures, and traditional dichotomies of Western thought have identified women with nonreason and nature, thus constructing the female gender as non-suitable for politics (Cavarero 2002). In other words, women have stayed away from politics insofar as politics has kept them at a distance.

In the postwar period in Italy, a number of feminist groups began criticizing the scant political space left in a country divided between left-wing parties that failed to prioritize women's aspirations and a Christian Democrat Party that was close to the Catholic Church. Only in the 1970s did feminist movements effectively call attention to gender in politics, resulting in struggles that had a great impact on the political domain. Women's achievements throughout this period range from attaining a national plan for nurseries and building family planning clinics, to reforming family rights and work legislation. Nevertheless, over the years, political participation was contested as being a "matter for men" since the private domain was in itself a "sufficiently political sphere" (Weber 1981), distancing women from institutional and visible political activities. In a way (feminist), social movements were the only option available to women to counterbalance invisibility within the political left, absorbing much of their energy for mobilization, and subsequently precluding them from exploiting a later opening of left-wing parties (Mulé 2011). Unlike in other countries, Italian feminist movements in the second half of the 1970s accentuated their orientation toward cultural and micro social objectives, with a significant and conscious silence over the traditional party-dominated political arena (Ergas 1982). At the same time, as radical feminists represented a substantial part of the women's movement in Italy, political institutions continued to be considered as the concretization of patriarchal power and male culture in the country, pushing politically active women to prefer more informal, or unconventional patterns of aggregation and mobilization. As a result, Italian women are still among the most underrepresented in formal political institutions across Western democratic countries (Eige 2016; Guadagnini 1993; Morales 2009), further sustaining the social construction of politics as not apt for women. 


\section{Hypotheses, Data, and Methods}

A review of the empirical research on how structural, situational, and cultural factors combine with a gender perspective supports a gendered political participation, and frames the theoretical context for studying the Italian case. In an ideal world, we should be able to test political participation against structural, situational, and cultural factors, but the reality is that our dataset has robust indicators only for the first two of these three aspects. Nevertheless, the Italian case offers interesting evidence of how structural and situational constraints affect political participation (It's Not Just a Matter of Time), opening up discussion about cultural factors (Discussion).

Our core hypothesis is that women tend to participate less in political activities primarily due to scarcity of time. We use "family arrangements" and "domestic work" as two indicators for situational constraints because they imply time-demanding tasks. Our hypothesis can now be split into two parts for the purpose of testing. First, we expect a lower level of participation in political activities for women when they are spouses or mothers (especially of pre-school aged children), as well as for women responsible for the entirety of domestic work in the household, or at least to a higher degree (Hypothesis 1) than men.

Therefore, if women have less time for political actions, we expect a similar depressive effect over a wider range of activities, not only confined to the domain of politics: situational constraints penalize women in all political and non-political contexts (Hypothesis 2). To test this second hypothesis related to time-availability, we consider time spent in activities related to social participation and time devoted to leisure. It is important to note here that social participation and leisure activities are not the focus of our investigation: we use them simply as a benchmark for political activities, to test whether scarcity of time due to situational factors has a similar depressive effect on these aspects.

Our reference dataset is the Multipurpose National Survey Aspects of Daily Life, conducted by Istat (Italian National Institute of Statistics) every year since 1993. This survey is run on a representative and large sample of the Italian population (nearly 50,000 individuals and 25,000 households) and covers a wide range of topics, such as family life, public services, mobility, and Information and Communication Technologies. Although not specifically designed as an electoral or political study, it offers a rich set of variables about family composition, age of children, hours of domestic work (including caring duties, errands, and chores), in addition to a large set of indicators of participation: political activities within parties and institutional bodies, political mobilization, engagement in social, and leisure activities. This dataset presents the great advantage of directly interviewing each member of the family, thus offering some important control variables. We chose data collected in 2011 and selected, from the original dataset, a subsample of 15,987 individuals in 
the 18-55 age bracket (of whom 53.7\% are women) which leads to a more homogeneous family structure. This procedure allowed us to focus on men and women who share similar life-course stages, living as couples or single parents with children.

\section{Dependent Variables}

We grouped all political activities available in our main database (Istat) and categorized them as: (a) visible participation (attending party meetings, donating, or raising money for a party; doing unpaid work for a party; attending a rally; attending political meetings); (b) invisible participation (getting political information; talking about politics). Indicators of visible participation are dichotomous (coded 0-1), while invisible participation is captured by categories of frequency ("Every day", "A few times a week", "Once a week", "A few times a month", "A few times a year", "Never"). As previously discussed, this typology is clear-cut in combining richness and effectiveness among different forms of participation. To detect gender dynamics outside of the political domain, we also considered: (c) social participation (attending meetings in charity, environmental, or cultural associations, 3 items, coded $0-1)$; (d) leisure activities (going to the cinema, theatre, museums, classical music concerts, other concerts, sports, discos, monuments, 9 items, categorized as "Never", "1-3 times", “4-6 times", "7-12 times", "More than 12 times in a year").

Our four dependent variables (visible political participation, invisible political participation, participation in social activities, and involvement in leisure activities) are indexes of the above-mentioned indicators reshaped into an equivalent $0-10$ scale. The scalability of items was tested with a Mokken Scale Analysis. Our case satisfies the required conditions for scalability, with Loevinger's $H$ coefficients higher than 0.30 for the overall scale and each item. In particular, Loevinger's $H$ for the overall scale is 0.44 for "visible participation", 0.46 for "social participation", and 0.43 for "leisure activities" (invisible participation does not require a similar procedure since it is based only on two indicators).

\section{Independent Variables}

We consider two situational factors as independent variables. The first is that of "Family arrangements" modeled by matching information on marital status, and the number and age of children. It is categorized as follows: "single" (2518 cases, $15.0 \%)$, "couple without children" $(2128,14.9 \%)$, "couple with at least one child aged 0-3" (2596, 16.0\%), "couple with children aged 4-6" (1604, 9.9\%), "couple with children aged 7+" (7141, 44.7\%). We created a new dataset where each row includes an individual (18-55 years) plus her/ his partner plus child/children. This means that every son or daughter, if younger than 18, appears in the same row as their parents. This procedure 
made it possible to determine the exact age of the children (while in the original dataset it was available only in an age-bracket), allowing us to distinguish and create three critical age categories: $0-3,4-6$, and $7+$ years old. The assumption holds that the younger the children, the heavier are the situational constraints that limit women's time availability.

Our second independent variable is "Domestic work", measured in hours spent per week ${ }^{2}$ over a wide range of activities (caring for other family members, chores, etc.) that reflects the division of domestic duties. Domestic work has a direct influence on actual available time for other activities and it echoes family arrangements that are, at least in part, an outcome of socially constructed gender roles. Unsurprisingly, our data show that in $201131 \%$ of men report no hours of domestic work against $2 \%$ of women, whilst the weekly mean value is $6 \mathrm{~h}$ for men against 27 for women, confirming data from the Harmonized European Time Use Survey (HETUS). Comparatively at the European level, Italian men of all ages are those who contribute the least to domestic work, whereas Italian women-when they turn 25 years-oldincreasingly spend greater time in domestic work (Zannella 2012).

We produced both descriptive and multivariate analyses to test our research hypothesis about structural and situational variables limiting time availability. First, we describe engagement profiles for men and women in political, social, and leisure activities (tables 1 and 2). Then, we perform distinct negative binomial regression models for men and women in order to assess the effects of our situational factors (the above-mentioned two independent variables) for each type of activity assumed as the dependent variable (tables 3 and 4). We also show the predicted scores of participation through informative plots for political and non-political activities (figure 1 on family arrangements and figure 2 on domestic work).

Finally, we tested the mean differences in political and non-political participation between men and women, according to different levels of domestic work (table 5). This allows us to better examine the magnitude and significance of the gender gap in political and non-political participation.

With regard to structural factors influencing political participation-such as education, age, occupational status, and region of residence-we treated socio-demographic features ${ }^{4}$ in our sample as covariates, in line with the classic literature on political and social participation (Barnes and Kaase 1979; Norris 2002; Van Deth, Montero, and Westholm 2007). Although the available dataset allowed for a relatively good overlapping with Jennings and Farah's categories of situational and structural constraints (Overview of Past Research), we acknowledge one possible limitation. Treating situational and structural factors as separate might introduce operational difficulties (Bennet and Bennet 1989), but other research diminished the relevance of structural factors (Andersen and Cook 1985; McDonagh 1982) supporting our decision to consider the latter as covariates. 
Table 1. Participation in visible and invisible political activities (at least once in the last 12 months, \%) by gender, difference, and sig test

\begin{tabular}{lrrrr}
\hline & Men & Women & $\begin{array}{l}\text { W M } \\
\text { (difference) }\end{array}$ & $\begin{array}{l}\text { Sig. test } \\
\text { (Cramer's V) }\end{array}$ \\
\hline Visible Political Activities & & & & \\
Direct involvement in a political party & 7.3 & 2.5 & 4.8 & 0.113 \\
Donate or raise money for a party & 3.8 & 2.1 & 1.7 & 0.053 \\
Volunteering for a party & 2.6 & 0.7 & 1.9 & 0.072 \\
Attended a rally & 6.6 & 5.2 & 1.4 & 0.029 \\
Attended a political meeting & 9.5 & 5.2 & 4.3 & 0.083 \\
Invisible Political Activities & & & & \\
Getting Political Information & & & & \\
Every day & 47.3 & 34.1 & 13.2 & 0.175 \\
More than once a week & 24.6 & 23.4 & 1.2 & \\
Once a week & 4.4 & 4.2 & 0.2 & \\
More than once a month & 7.4 & 9.0 & 1.6 & \\
More than once in a year & 3.9 & 5.8 & 1.9 & \\
Never & 12.3 & 23.4 & 11.1 & \\
Talking about politics & & & & \\
Every day & 16.6 & 9.2 & 7.4 & 0.211 \\
More than once a week & 33.4 & 23.4 & 10.0 & \\
Once a week & 6.6 & 5.4 & 1.2 & \\
More than once a month & 16.5 & 16.9 & +0.4 & \\
More than once in a year & 9.0 & 11.9 & +2.9 & \\
Never & 17.9 & 33.2 & +15.3 & \\
N & 7,443 & 8,633 & & \\
\hline
\end{tabular}

Source: Istat 2011.

\section{It's Not Just a Matter of Time}

A preliminary comparison between women and men on a large array of political, social, and leisure activities offers a general overview on gender gaps in Italy (tables 1 and 2). Our findings reported in table 1 show that men are more likely to participate in any form of visible political participation, from party activities to different actions of political mobilization, especially when attending political meetings. Women prove significantly less active than men, both in terms of political information and propensity to discuss politics. The gender difference is $7 \%$ points higher for men when "talking everyday" about politics (16\% of men and 9\% of women); 13\% points for women when it comes to daily information ( $47 \%$ of men vs. $34 \%$ of women look for information every day). Sharp differences stand out in the collection of political 
Table 2. Engagement in social and leisure activities (at least once in the last 12 months, \%) by gender, difference, and sig. test

\begin{tabular}{lrrrc}
\hline & Men & Women & $\begin{array}{l}\text { W M } \\
\text { (Difference) }\end{array}$ & $\begin{array}{l}\text { Sig. test } \\
\text { (Cramer's V) }\end{array}$ \\
\hline Social Activities (have attended meetings) & & & & \\
Charity association & 10.0 & 8.3 & 1.7 & 0.030 \\
Environmental association & 2.1 & 2.0 & 0.1 & 0.002 \\
Cultural association & 13.0 & 9.8 & 3.2 & 0.050 \\
Leisure Activities (have done) & & & & \\
Cinema & 59.8 & 59.3 & 0.5 & 0.005 \\
Theatre & 20.3 & 24.5 & +4.2 & 0.051 \\
Museum & 30.8 & 31.9 & +1.1 & 0.021 \\
Classical music concerts & 10.6 & 11.1 & +0.5 & 0.008 \\
Other concerts & 24.7 & 23.5 & 1.2 & 0.014 \\
Sport & 44.7 & 21.6 & 23.1 & 0.247 \\
Disco & 23.5 & 20.1 & 3.4 & 0.041 \\
Visiting monument & 26.5 & 25.0 & 1.5 & 0.017 \\
$N$ & 7,443 & 8,633 & & \\
\hline
\end{tabular}

Source: Istat 2011.

information ( $12 \%$ of men and $23 \%$ of women never get informed) and in political discussion (respectively, $18 \%$ and $33 \%$ never talk about politics). Thus, women undergo the process of cognitive mobilization to a lower extent than men.

If we consider social and leisure activities, a different scenario emerges (table 2). Stark differences disappear. Activism in charity work and environmental associations does not penalize women, and only participation in cultural groups shows a significantly higher presence of men. As for leisure activities, only practicing a sport is a heavily gendered activity ( $45 \%$ of men against $22 \%$ of women), which can easily be explained through the social construction of gender. ${ }^{3}$ To summarize, this descriptive exercise shows that the Italian case follows well-known gender dynamics when it comes to political participation compared to social and leisure activities.

Let us now turn to the core question of our investigation about men and women's likelihood of participating by using predicted probabilities of involvement in political (visible and invisible), social, and leisure activities. We ran four distinct regression models for men and women, using a negative binomial regression ${ }^{5}$, gathering evidence for the first independent variable (family arrangements), and, then, for second one (domestic work). Table 3 reports the estimates of the models, while the top two plots of figure 1 visualize the 


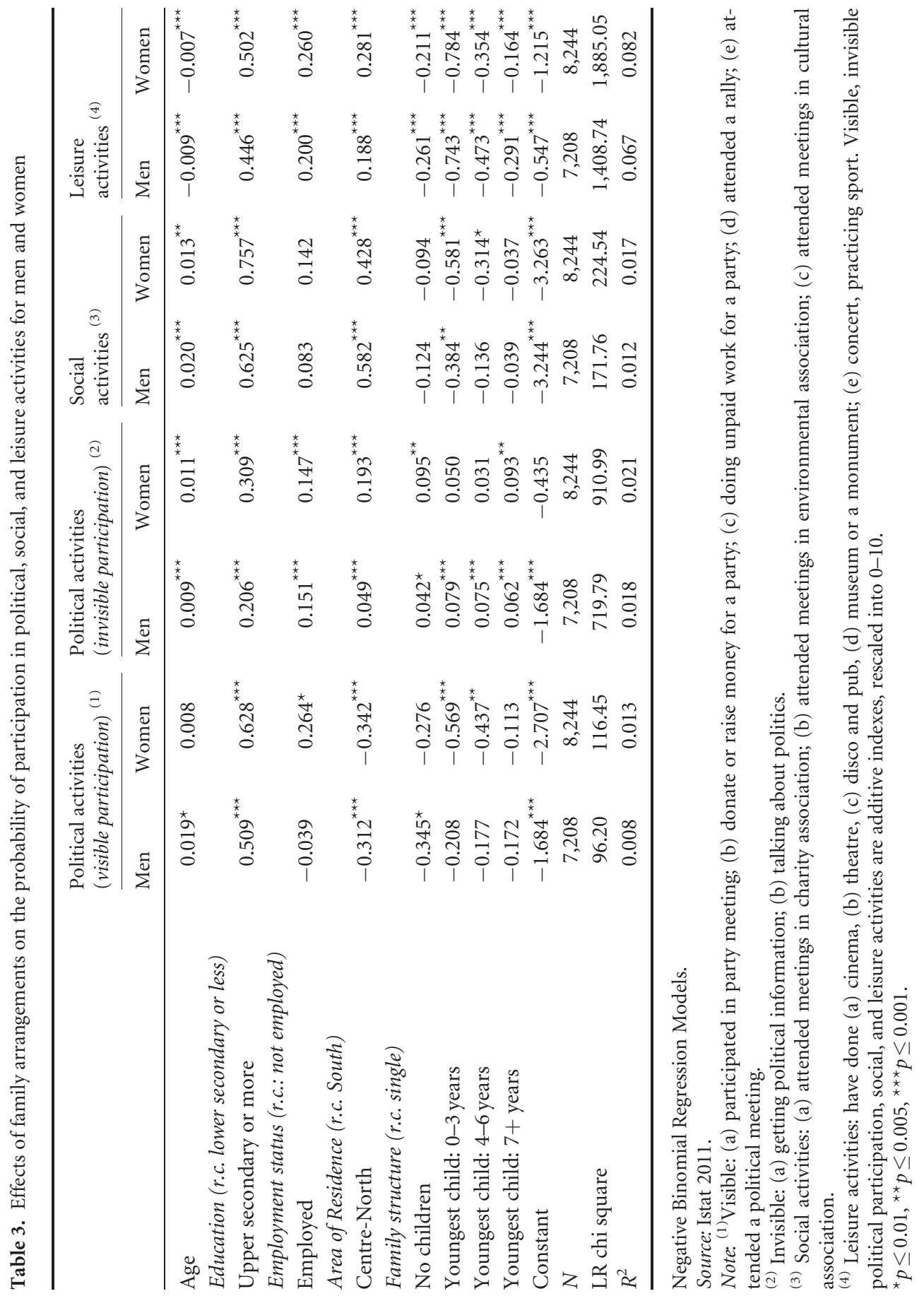




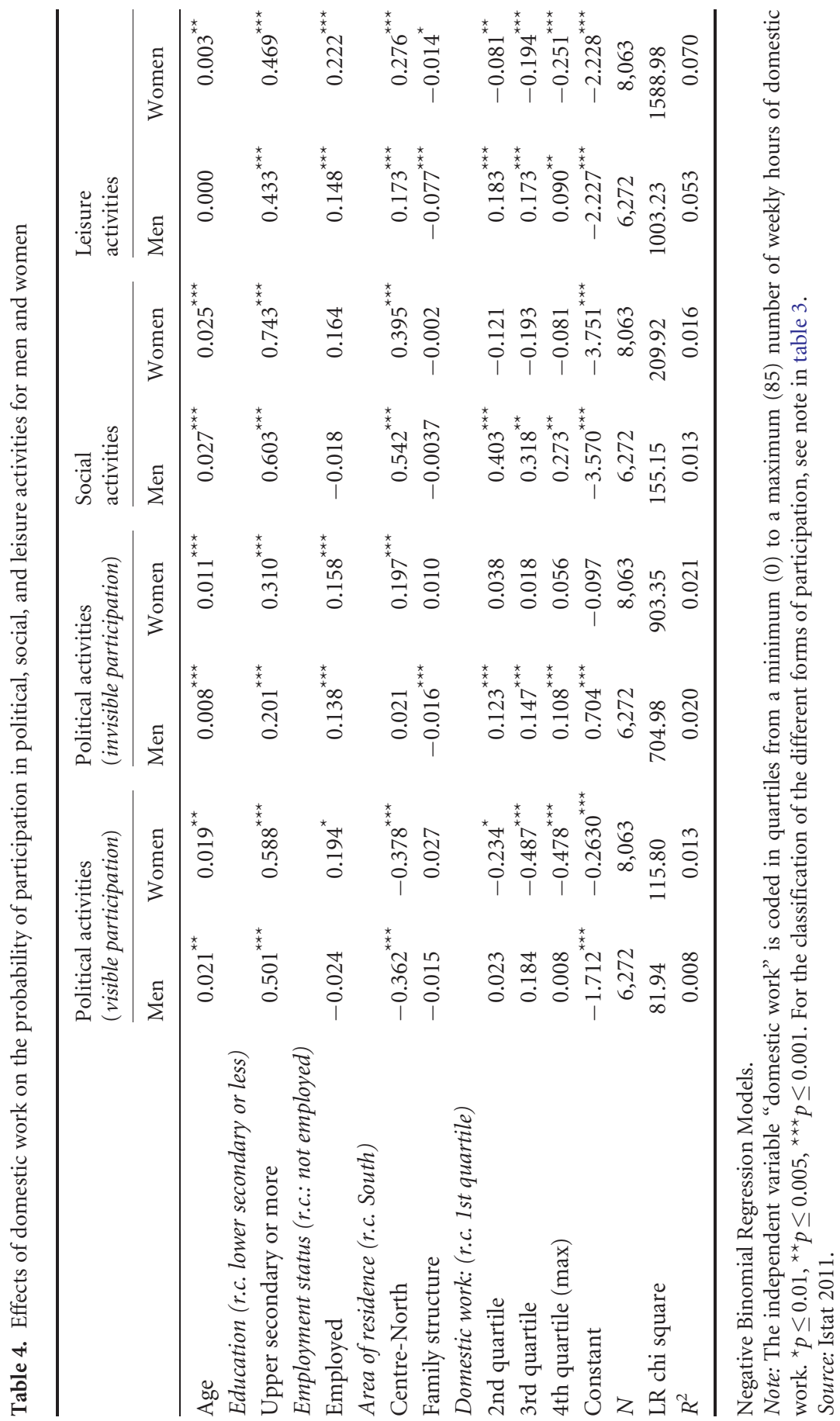



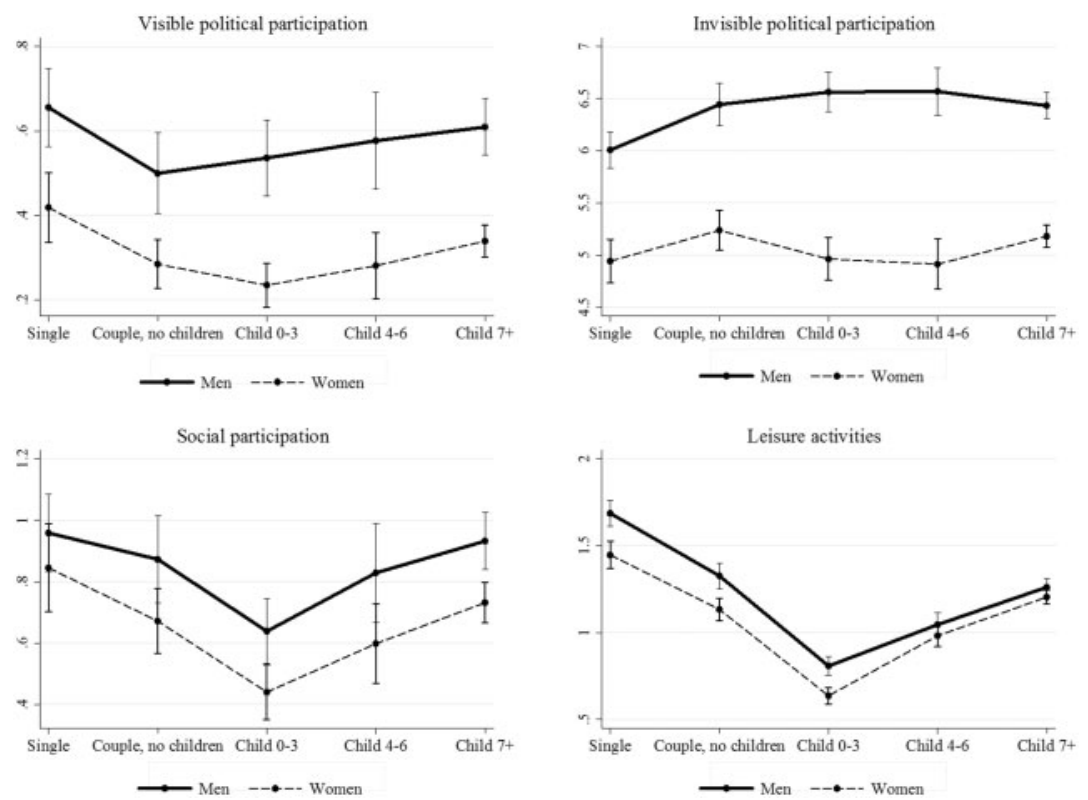

Figure 1. Predicted values of engagement in (visible and invisible) political, social, and lei sure activities (scale 010 ) for men and women by family arrangements.
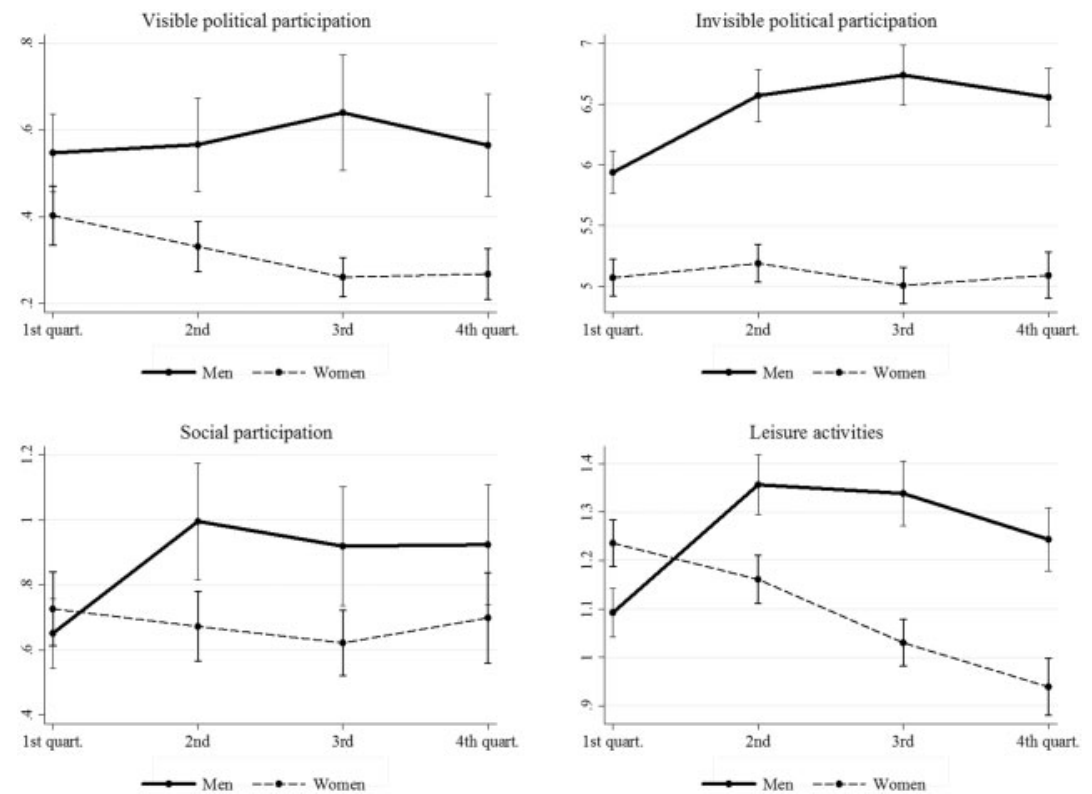

Figure 2. Predicted values of engagement in (visible and invisible) political, social, and lei sure activities (scale 010 ) for men and women by domestic work. 
Table 5. Means scores and gender differences in political and non political participation by levels of domestic work; significance of differences (Mann Whitney test)

\begin{tabular}{lccccc}
\hline & Men & Women & Diff. M W & $z$ score & $p(\mathrm{z})$ \\
\hline Visible political participation & & & & & \\
1st quartile (min) & 0.55 & 0.43 & 0.12 & +1.71 & 0.047 \\
2nd quartile & 0.57 & 0.33 & 0.24 & +5.44 & 0.000 \\
3rd quartile & 0.66 & 0.25 & 0.41 & +8.18 & 0.000 \\
4th quartile (max) & 0.56 & 0.22 & 0.34 & +7.85 & 0.000 \\
Invisible Political Participation & & & & & \\
1st quartile (min) & 5.85 & 5.45 & 0.40 & +3.88 & 0.000 \\
2nd quartile & 6.82 & 5.39 & 1.43 & +12.86 & 0.000 \\
3rd quartile & 6.93 & 4.74 & 2.19 & +18.41 & 0.000 \\
4th quartile (max) & 6.56 & 4.46 & 2.10 & +16.62 & 0.000 \\
Social Participation & & & & & \\
1st quartile (min) & 0.58 & 0.88 & 0.30 & 5.90 & 0.000 \\
2nd quartile & 0.99 & 0.70 & 0.29 & +5.18 & 0.000 \\
3rd quartile & 0.95 & 0.56 & 0.39 & +6.49 & 0.000 \\
4th quartile (max) & 0.86 & 0.50 & 0.36 & +5.72 & 0.000 \\
Leisure activities & & & & & \\
1st quartile (min) & 1.02 & 1.48 & 0.46 & 11.46 & 0.000 \\
2nd quartile & 1.48 & 1.21 & 0.27 & +6.66 & 0.000 \\
3rd quartile & 1.45 & 0.91 & 0.54 & +12.94 & 0.000 \\
4th quartile (max) & 1.27 & 0.74 & 0.53 & +11.89 & 0.000 \\
\hline
\end{tabular}

Note: 010 range for all indexes

(predicted) values, for men and women, of visible and invisible political participation according to different family arrangements (single, couple, with children of different ages). The lower two show the same relation concerning social and leisure activities.

Three notable results emerge: family arrangements "dry out" women's time for politics, except for invisible political activities; they have a similar negative effect on non-political activities (especially for leisure) and have an analogous "drying effect" on men.

Overall, union formation and transition to parenthood depress women's participation over a wide range of activities, but do not negatively impact invisible political participation. Women moving from "single" to "partner with a $0-3$ child" implies a change in values from 0.4 to 0.2 for visible political participation, from 0.8 to 0.5 for social activities, and from 1.5 to 0.6 for leisure activities. Predicted scores for invisible political activities do not vary if a woman changes from being single to forming a couple, and to having 
children. This apparent anomalous result is self-explaining if we consider its peculiar characteristics: invisible participation does not necessarily require a personal direct outside-of-the-home effort and is less time-consuming. Also, invisible actions could be performed in parallel with other activities (such as offline and online groceries or shopping), dovetailing with family schedules and offering leverage for integration, as discussed in the "Types of Engagement and Political Participation" section.

Leisure activities are the most penalized by the presence of very young children in the household, followed by participation in social activities. At a comparative level, gender gaps in time allocation between paid work, domestic work, and leisure tend to increase with parenthood in light of institutional factors (family policies and employment regimes) and prevailing social norms. Italy shows the largest gender gaps with specific institutional (limited supply of childcare; rigidity of the labor market) and cultural (traditional gender roles) features. Evidence is also consistent with a "crystallization of gender roles": transition to parenthood orients women towards devoting more time to family activities, with a parallel decrease in leisure (Lundberg 2005). As a result, Italian fathers enjoy additional leisure time, away from children, while mothers do not (Craig and Mullan 2013).

Surprisingly, family arrangements play a similar role in the lives of men. Though to a lesser extent, their effect holds true for men, except in the case of invisible political activities. Fathers with pre-school aged children (0-3) experience the same decline in visible political, social, and leisure activities as women do, which gradually tails off when children grow older. This generalized negative effect suggests that younger children are more of a constraint than a connection for political participation (as discussed in the "Structural and Situational Constraints on Political Participation" section). This is no surprise in Italy since there is a substantial gap in the coverage of pre-school enrollment for children aged 0-3 years compared to other age classes. At a national level, the supply for public and publicly co-funded nurseries for $0-3$ year-old children covers only $11 \%$ of demand, whereas the educational supply for children over 4 years of age is almost equal to the demand (Istat 2014). Thus, having a 0-3 year-old child can explain the difference because it involves a greater load of time-consuming duties, keeping both parents away from different types of participation.

Let us now consider the second variable that is the key to understanding gender gaps in participation: the time dedicated to domestic work. As a concrete indicator of how women and men organize and redistribute their time, this variable can show how situational factors contain or enhance participation. As in table 3, table 4 reports negative binomial regression models where the coefficients reflect the impact of domestic work ${ }^{6}$ on visible and invisible political participation and on social and leisure activities. Similarly to figure 1 , figure 2 shows predicted values of the four dependent variables for men and women according to the load of domestic work. 
Our evidence suggests three effects: domestic work is negatively associated with visible political participation, draining away women's time from politics, except for invisible political activities; it has a similar negative effect on nonpolitical types of engagement (especially on leisure); its effect unfolds differently for men.

As for the previous indicator, an increase in hours spent on housework duties reduces the level of participation among women in the visible political domain while it does not significantly impact invisible political activities that are configurable as a flexible and individualized type of engagement compatible with other daily routines.

Leisure activities are the most penalized, with a linear decrease from a value of 1.3 when domestic load is low (1st quartile) to 0.9 (4th quartile) when it is higher. As previously pointed out, institutional factors and traditional gender roles help explain the strong effect domestic work has on leisure time, even compared with family arrangements. The domestic workload plays out differently on men's engagement, as they seem to manage a busier schedule. While women usually subtract time from participation as domestic work increases, men persist in (any kind of) participation until the load of domestic duties reaches the highest level (4th quartile). To summarize, the data show that domestic work has a negative impact on women's ability to participate, but net women-men differences between political and non-political activities (figure 1) push the investigation a step further to assess the significance of time constraints on the political gender gap.

Following our core hypothesis, in the absence of time constraints, women's engagement level should equal that of men's. Table 5 reports the mean scores by gender on the four dimensions of participation for each level of domestic work. We used the Wilcoxon rank (Mann-Whitney) non-parametric test to evaluate the distribution of scores for both groups of the independent variable (gender). An interesting point to note is that without situational constraints on time availability (1st quartile of domestic work) women still do not participate in political activities, while they engage more in social and leisure activities. Within the political domain, the male-female difference is barely significant for visible participation ( $z$-score 1.71), but significant for invisible participation ( $z$-score 3.88). Gender gaps in favorable situations do not replicate in social and leisure participation: outside of politics, women not only match, but even overtake men in their participatory styles. Women in the 1st quartile register negative and high $z$-scores. Such a result suggests an additional explanation that we identify as a "cultural constraints hypothesis", which is discussed in the next section. 


\section{Discussion}

Overall, do situational constraints account for the sharp gender gap in politics? Do they impact political and non-political activities to the same extent? Evidence is multifaceted, but complementary to the multidimensional theoretical framework we built. Situational constraints are alive and kicking since women are still penalized in their political engagement, especially under specific onerous conditions (younger children and high loads of domestic work). Our hypotheses 1 and 2 are thus confirmed, showing that time constraints affect and contain women's participation in both political and non-political activities, with the sole exception of invisible political activities.

Yet, the situational explanation does not account for all of the evidence we found, suggesting an additional hypothesis on "cultural constraints", as initially introduced by Welch (1977). Women do indeed register lower levels of political participation compared to men at any stage in their life-course and with any load of domestic work (figure 2). Had the hypothesis of situational constraints been the exclusive explanation, without familiar constrictions women and men should register similar starting levels of participation that diverge as life-course stages unfold. Instead, women always demonstrate a lower level of engagement in (visible and invisible) political activities, even under favorable conditions, such as those without time-demanding family roles.

This illuminates the specific relationship that women are proven to have with politics in Italy: situational constraints might deepen participatory gaps, but do not account for their origins. Cultural constraints are, therefore, the additional explanation: different paths in political socialization, attitudes towards conflict and power, perceived distance from political issues, self-efficacy in the political domain, and public perception as more suitable to the private sphere (including consumption related and leisure activities) lead Italian women to underdevelop their interest in politics and prioritize areas of interest differently from men. This is a key finding that calls for further investigation of the social roots of the gender gap in politics.

Although only partially debated and explained in the Italian context, the gender gap in political participation is a long-standing puzzle in the political and social sciences. Our study sheds light on situational constraints (measured through "family arrangements" over the course of life and the load of "domestic work") that play a role in inhibiting women's political participation. Women do tend to juggle different activities, having less time at their disposal due to situational constraints. Yet it is not just a matter of time. Time limitations do not hinder political participation more than they do social and leisure activities, suggesting that gender differences might be explained through some additional elements. In fact, the existence of situational constraints that lower participation do not alone explain why women without time-demanding family roles engage significantly less than men do in politics. 
This result raises the question of "cultural constraints" that, coupled with situational constraints, lean in and encourage women to refrain from participation. Gendered paths in political socialization, attitudes towards conflict, perceived distance from political issues, interest in politics, and self-perceived efficacy are the underlying explaining mechanisms of a gendered political participation. In sum, our study on the gender gap in political participation reveals the importance but also the complexity of such an issue, which requires adequate conditions to be correctly investigated: a wider array of engagement indicators, more precise indicators about family arrangements (panel data would be ideal), measures for cultural constraints along with larger datasets, comparisons over time, and across countries.

Nevertheless, some of the basic dynamics detected in this article represent a starting point for a deeper study that intersects sociological and political perspectives in search of the social roots of the gender gap in politics. Backing Hayes and Bean's conclusion in their 1993 work, we believe that there is still a need for reworking the traditional territory of political analysis that takes into account not only conventional political activities (such as electoral behavior or institutional representation), but also unconventional political and social activities that might reflect a wider range of concerns and the diversity of women's political experiences. For this reason, an innovative approach to studies on political participation through a gender perspective seems promising, especially in countries such as Italy, where traditional gender norms still strongly affect attitudes and behaviors.

\section{Notes}

Laura Sartori is an Associate Professor in the Department of Political and Social Sciences at the University of Bologna. Her research interests span over a broad range of topics, from digital divide and digital inequalities to open government, political participation and digital social innovation with a specific focus on gender. She is a member of the editorial board of Polis (Journal of Politics and Society in Italy).

Dario Tuorto is an Associate Professor in the Department of Education at the University of Bologna. His main research interests concern political turnout, party activism, youth political and social involvement, family change and transitions to adulthood. He is a member of the editorial board of Polis (Journal of Politics and Society in Italy).

Rossella Ghigi is an Associate Professor in the Department of Education at the University of Bologna. Her research interests deal with gender studies, sociology of consumption and gender socialization. She is a member of the editorial board of the Rassegna Italiana di Sociologia (Italian Review of Sociology) and of the Italian Association of Sociology's Gender Studies Section. 
1. The legacy of Catholicism coupled with authoritarian institutions have long relegated women exclusively to the private domain, by publicly recognizing their value in their role as wives and mothers, and refusing them the right to vote in political elections until after the Second World War. In the 1950s and 1960s, the Catholic tradition had a major influence on the political socialization of both men and women, but it affected women's behavior to a greater extent due to a complex set of factors such as labor market exclusion, domestic seclusion, and lower levels of education (Weber 1981). As a result, women opted out of politics and turned to the private sphere: the church often represented the only extra familiar point of reference offering a strong ideological structure (Dogan 1963).

2. Like many other variables relating to time dedicated to daily or weekly activi ties, "domestic work" has a non normal distribution. Most cases cluster in the cate gories of "a full hour" or "half hour", whilst only a minority of individuals indicates exactly the minutes devoted to domestic work. A better estimation of coefficients and curve fitting requires transforming minutes into hours $\left(\begin{array}{l}0 \\ 0\end{array} 0^{\prime} \mathrm{min}=1 / 2 \mathrm{~h}\right.$ and 3160 ' $\min =1 \mathrm{~h}$ ) and recoding them into quartiles (figure 2 ).

3. Model control for Education (dichotomy: lower secondary education or less/upper secondary education or more), Age (continuous), Employment status (dichotomy: not employed/employed); Area of residence: aggregation of Istat standard classification (dichotomy: South/Center North).

4. For an overview of explanations about female participation in sport, see Scraton and Flintoff (2002).

5. The negative binomial regression is modeled for count variables where the mean is significantly lower than the variance. The choice depends on the high level of positive skewness (values are grouped on the left tail of the distribution).

6. "Domestic work" is expressed in quartiles (from a minimum of $0 \mathrm{~h}$ to a maximum of $85 \mathrm{~h}$ per week).

\section{References}

Andersen, Kristi, and Elisabeth A. Cook. 1985. Women, work and political attitudes. American Journal of Political Science 19 (3): 43953.

Amato, Paul R. 2000. The consequences of divorce for adults and children. Journal of Marriage and the Family 62: 126987.

Anxo, Dominique, Letizia Mencarini, Ariane Pailhé, Anne Solaz, Maria Letizia Tanturri, and Lennart Flood. 2011. Gender differences in time use over the life course in France, Italy, Sweden, and the US. Feminist Economics 17 (3): 15995.

Barnes, Samuel H., and Max Kaase. 1979. Political action. Mass participation in five western democracies. Beverly Hills, CA: Sage.

Bennett, Linda L. M., and Stephen Earl Bennett. 1989. Enduring gender differences in political interest. American Quarterly Politics 17 (1): 10522.

Bernstein, Arla G. 2005. Gendered characteristics of political engagement in college stu dents. Sex Roles 52: 299310.

Bode, Leticia. 2016. Closing the gap: Gender parity in political engagement on social media. Information, Communication \& Society, 2: 117. 
Bonomi Romagnoli, Barbara. 2014. Irriverenti e libere: Femminismi nel nuovo millennio. Roma: Editori Internazionali Riuniti.

Bordandini, Paola, Aldo Di Virgilio, and Rosa Mulé. 2011. I leader degli anni a venire. Atteggiamenti e opinioni dei delegati di partito in Italia. Polis 2: 15970.

Brunelli, Giuditta. 2006. Donne e politica. Bologna: Il Mulino.

Burns, Nancy. 2007. Gender in the aggregate, gender in the individual, gender and po litical action. Politics \& Gender 3: 10424.

Burns, Nancy, Kay L. Schlozman, and Sidney Verba. 1997. The public consequences of private inequality: Family life and citizen participation. American Political Science Review 91: 37389.

. 2001. The private roots of public action. Gender, equality, and political participa tion. Cambridge, MA: Harvard University Press.

Cartocci, Roberto. 2011. Geografia dell'Italia cattolica. Bologna: Il Mulino.

Cavarero, Adriana. 2002. Stately bodies. Michigan University Press: Ann Arbor.

Chibber, Pradeep. 2002. Why are some women politically active? The household, pub lic space, and political participation in India. International Journal of Comparative Sociology 43: 40929.

Clark, Cal, and Janet Clark. 1986. Models of gender and political participation in the United States. Women \& Politics, 6 (1): 525.

Coffé, Hilde. 2013. Women stay local, men go national and global? Gender differences in political interest. Sex Roles 69 (5 6): 32338.

Coffé, Hilde, and Catherine Bolzendahl. 2010. Same game, different rules? Gender dif ferences in political participation. Sex Roles 62: 31833.

Conway, Margaret, David W. Ahern, and Gertrude Steuernagel. 2004. Women and po litical participation: Cultural change in the political arena. Washington, D.C.: CQ Press.

Corbetta, Piergiorgio, and Nicoletta Cavazza. 2008. From the parish to the polling booth: Evolution and interpretation of the political gender gap in Italy, 19682006. Electoral Studies 27 (2): 27284.

Craig, Lyn, and Killian Mullan. 2010. Parenthood, gender and work family time in USA, Australia, Italy, France and Denmark. Journal of Marriage and Family 72 (5): 13441361.

. 2013. Parental leisure time: A gender comparison in five countries. Social Politics 20 (3): 32957.

Dalton, R. J. 1984. Cognitive mobilization and partisan dealignment in advanced in dustrial democracies. Journal of Politics 46: 26484.

Dogan, Mattei. 1963. Le donne italiane tra cattolicesimo e marxismo. In Elezioni e com portamento politico in Italia. ed. Alberto Spreafico and Josef LaPalombara. Milano: Comunità, 47594 .

1967. Political cleavage and social stratification in France and Italy. In Party systems and voter alignments, ed. Seymour M. Lipset and Stein Rokkan, 12995. New York: The Free Press.

Dow, Jay K. 2009. Gender differences in political knowledge: Distinguishing characteristics based and returns based differences. Political Behavior 31 (1): 11736.

Dotti, Sani, and Giulia Maria. 2012. La divisione del lavoro domestico e delle attività di cura nelle coppie italiane: Un'analisi empirica. Stato e Mercato 94: 16193. 
Ekman, Joakim, and Erik Amna. 2012. Political participation and civic engagement. Human Affairs 22: 283300.

Ergas, Yasmine. 1982. 1968 79. Feminism and the Italian party system: Women's poli tics in a decade of turmoil. Comparative Politics, 14 (3): 25379.

Eige (European Institute for Gender Equality). 2016. Gender equality index 2015 report, European Commission. Available from: http://eige.europa.eu/gender statistics.

Eurostat, 2016. Employment statistics. Last modified June 32016 , accessed September 25, 2016. Available from: http://ec.europa.eu/eurostat/statistics explained/index. php/Labour market.

Ferrera, Maurizio. 1996. The "southern model" of welfare in social Europe. Journal of European Social Policy 6 (1): 1737.

Fox, Richard L., and Jennifer L. Lawless. 2014. Uncovering the origins of the gender gap in political ambition. American Political Science Review 108 (3): 499519.

Fraile, Marta. 2014. Do women know less about politics than men? The gender gap in political knowledge in Europe. Social Politics 21 (2): 26189.

Fraser, Nancy. 1997. Justic interruptus. New York: Routledge.

Fridkin, Kim, and Patrick Kenney. 2007. Examining the gender gap in children's atti tudes toward politics. Sex Roles 56: 13340.

Gallagher, Sally K., and Gerstel Naomi. 2001. Connections and constraints: The effects of children on caregiving. Journal of Marriage and Family, 63: 26575.

Gallego, Aina. 2008. Unequal political participation in Europe. International Journal of Sociology 37 (4): 2025.

Guadagnini, Marila. 1993. A 'partitocrazia' without women: The case of the Italian party system. In Gender and Party Politics, ed. Jony Lovenduski and Pippa Norris, 168 204. New York: Sage.

Harris, Anita. 2008. Young women, late modern politics, and the participatory possi bilities of online cultures. Journal of Youth Studies 11 (5): 48195.

Hayes, C. Bernardette, and S. Clive Bean. 1993. Gender and political interest: Some in ternational comparisons. Political Studies XLI: 67282.

Helms, Sara, and Tom McKenzie. 2014. Gender differences in formal and informal vol unteering in Germany. Voluntas: International Journal of Voluntary and Nonprofit Organizations 25 (4): 887904.

Hobbs, R. William, A. Nicholas Christakis, and H. James Fowler. 2014. Widowhood ef fect in voter participation. American Journal of Political Science 58: 116.

Istat. 2014. L'offerta comunale di asili nido e altri servizi socio educativi per la prima infanzia. Roma: Istat.

Jennings, Kent. 1979. Another look at the life cycle and political participation. American Journal of Political Science 23 (4): 75571.

1983. Gender roles and inequalities in political participation: Results from an eight nation study. Western Political Quarterly 36 (3): 36485.

Jennings, Kent, and Barbara Farah. 1990. Gender and politics: Convergence or differen tiation? In People and their polities, ed. Risto Sankiaho, 27 66. Helsinki: Finnish Political Science Association.

Kalmijn, Matthijs, and Marjolein Broese van Groeno. 2005. Differential effects of di vorce on social integration. Journal of Social and Personal Relationships 22: 45576.

Kingston, Paul W., and Steven E. Finkel. 1987. Is there a marriage gap in politics? Journal of Marriage and Family 49: 5764. 
Kolinsky, Eva. 1989. Women in West Germany. Berg: New York.

Lister, Ruth. 2003. Citizenship: Feminist perspectives. New York: Palgrave Macmillan.

Lovenduski, Joni. 1998. Gendering research in political science. Annual Review of Political Science 1: 33356.

2005. Feminizing politics. Cambridge: Polity.

Lowndes, Vivien. 2004. Getting on or getting by? Women, social capital and political participation. The British Journal of Politics \& International Relations 6: 4564 .

Lundberg, Shelly. 2005. Sons, daughters, and parental behavior. Oxford Review of Economic Policy 21 (3): 34056.

Magaraggia, Sveva, and Giovanna Vingelli (eds.). 2015. Genere e partecipazione politica. Milano: Franco Angeli.

Mattingly, J. Marybeth, and Suzanne M. Bianchi. 2003. Gender differences in the quan tity and quality of free time: The U.S. experience. Social Forces 81: 9991030.

McDonagh, Eileen. L. 1982. To work or not to work: The differential impact of achieved and derived status upon the political participation of women, 19561976. American Journal of Political Science 26: 28097.

Mencarini, Letizia, and Maria Letizia Tanturri. 2004. Time use, family role set and childbearing among Italian working women. Genus LX (1): 11137.

Molfino, Francesca. 2006. Donne, politica e stereotipi: Perché l'ovvio non cambia? Milano: Baldini Castoldi Dalai.

Moore, Gwen. 1990. Structural determinants of men's and women's personal networks. American Sociological Review 55: 72635.

Morales, Laura. 2009. Joining political organizations. Institution, mobilization and partic ipation in Western democracies. Colchester: ECPR Press.

Mulè, Rosa. 2011. Delegati congressuali: Cos'è cambiato dopo trent'anni? Polis, 2: 26388.

Munch Anne, Miller McPherson, and Lynn Smith Loving. 1997. Gender, children and social contact: The effects of childrearing for men and women. American Sociological Review, 62: 50920.

Naldini, Manuela, and Chiara Saraceno 2011. Conciliare lavoro e famiglia: vecchi e nuovi patti tra sessi e generazioni. Bologna: Il Mulino.

Nedelman, Birgitta. 1987. Individuals and parties. Changes in processes of political mo bilization. European Sociological Review 3 (3): 181202.

Nomaguchi Kei M., and Melissa A. Milkie. 2003. Costs and rewards of children: The ef fects of becoming a parent on adults' lives. Journal of Marriage and Family, 65: 35674

Norris, Pippa. 2002. Democratic phoenix: Reinventing political activism. Cambridge: Cambridge University Press.

Parry, Geraint, George Moyser, and Neil Day. 1992. Political participation and democ racy in Britain. Cambridge: Cambridge University Press.

Pateman, Carole. 1970. Participation and democratic theory. Cambridge: Cambridge University Press.

Paxton, Pamela, Sheri Kunovich, and Melanie M. Hughes. 2007. Gender in politics. Annual Review of Sociology 33: 26384.

Piper, Greg, and Silke Schnepf. 2008. Gender differences in charitable giving in Great Britain. Voluntas: International Journal of Voluntary and Non profit Organizations, 19 (2): 10324. 
Pizzorno, Alessandro. 1993. Le radici della politica assoluta. Milano: Feltrinelli.

Quaranta, Mario. 2016a. Life course, gender and participation in voluntary organiza tions in Italy. Voluntas: International Journal of Voluntary and Non profit Organizations 27 (2): 87499.

2016b. Leaving home, finding a partner and having kids: A different look at the effects of life cycle transitions on political participation in Italy. Acta Politica 51 (3): 37297.

Rapoport, Ronald B. 1981. The sex gap in political persuading: Where the "structuring principle" works. American Journal of Political Science 25: 3248.

Ridgeway, Cecilia L. 2011. Framed by gender: How gender inequality persists in the mod ern world. New York, NY: Oxford University Press.

Romano, Clelia, Letizia Mencarini, and Cristina Freguja. 2012. Uso del tempo e ruoli di genere. Roma: Istituto Nazionale di Statistica, Istat.

Romano, Clelia, and Rita Ranaldi. 2008. Conciliare lavoro e famiglia Una sfida quo tidiana. Roma: Istituto Nazionale di Statistica, Istat.

Rotolo, Thomas. 2000. A time to join, a time to quit: The influence of life cycle transi tions on voluntary association membership. Social Forces 78: 11331161.

Sapiro, Virginia. 1982. Private costs of public commitments of public costs of private commitments? Family roles and political ambition. American Journal of Political Science 25: 26579.

Sarlo, Assunta, and Francesca Zajczyk. 2012. Dove batte il cuore delle donne? Voto e par tecipazione politica in Italia. Roma Bari: Laterza.

Sani, Giacomo. 1980. The political culture of Italy: Continuity and change. In The civic culture revisited, ed. Gabriel A. Almond and Sydney Verba, 273 324. Boston, MA: Little, Brown.

Sayer, Liana C. 2005. Gender, time, and inequality: Trends in women's and men's paid work, unpaid work, and free time. Social Forces 84: 285303.

Schlozman, Kay L., Nancy Burns, and Sidney Verba. 1994. Gender and the pathways to participation: The role of resources. Journal of Politics 56: 96390.

. 1999. 'What happened at work today?' A multistage model of gender, employ ment, and political participation. Journal of Politics 61: 2953.

Scraton, Sheila, and Anne Flintoff. 2002. Sport feminism. The contribution of feminist thought to our understandings of gender and sport. In Gender and sport: A reader, ed. Sheila Scraton and Anne Flintoff, 30 46. London: Routledge.

Smith, David Horton. 1994. Determinants of voluntary association participation and volunteering: A literature review. Non profit and Voluntary Sector Quarterly, 23: 24361.

Solera, Cristina. 2009. Women in and out of paid work: Changes across generations in Italy and Britain. Bristol: Policy Press.

Stake, Jayne. 2007. Predictors of change in feminist activism through women's and gender studies. Sex Roles 57: 4354.

Stoker, Laura, and Kent Jennings. 1995. Life cycle transitions and political participa tion: The case of marriage. American Political Science Review 89: 42133.

Stolle, Dietlind, Marc Hooghe, and Michele Micheletti. 2005. Politics in the supermar ket: Political consumerism as a form of political participation. International Political Science Review 26: 24569. 
Stolle, Dietlind, and Marc Hooghe. 2011. Shifting inequalities. Patterns of exclusion and inclusion in emerging forms of political participation European Societies 13 (1): 11942.

Sundstrom, Aksel, and Daniel Stockemer. 2015. What determines women's political representation at the local level? A fine grained analysis of the European regions International Journal of Comparative Sociology 56 (3 4): 25474.

Teorell, Jan, Mariano Torcal, and José Ramón Montero. 2007. Political participation: Mapping the terrain. In Citizenship and involvement in European Democracies: A comparative analysis, ed. Deth Jan van, José Ramón Montero and Anders Westholm, 334 57. New York: Routledge.

Jan Van, Deth, José, Montero, and Anders Westholm (eds.) 2007. Citizenship and in volvement in European democracies. A comparative analysis. London and New York: Routledge.

Vassallo, Francesca. 2006. Political participation and the gender gap in European Union member states. Journal of Contemporary European Studies 14 (3): 41127.

Verba, Sidney, Nancy Burns and Kay L. Schlozman. 1997. Knowing and caring about politics: Gender and political engagement. Journal of Politics 59: 10511072.

Verge Mestre, Tània, and Raul., Tormos Marín 2012. La persistencia de las diferencias de género en el interés por la política. Reis. Revista Española de Investigaciones Sociológicas 138, Abril Junio, 89108.

Voorpostel, Marieke, and Hilde Coffé. 2012. Transitions in partnership and parental status, gender, and political and civic participation. European Sociological Review 28 (1): 2842 .

Weber, Maria. 1981. Italy. In The politics of the second electorate, ed. Joni Lovenduski and Jill Hills, 182 208. London: Routledge and Kegan Paul.

Welch, Susan. 1977. Women as political animals? A test of some explanations for male female political participation differences. American Journal of Political Science 21 (4): 71130.

Wilson, John, and Mark A. Musick. 1997. Who cares? Toward an integrated theory of volunteer work. American Sociological Review 62: 694713.

Zannella, Marina. 2012. Il tempo è denaro: Un'analisi della produzione e del consumo di tempo all'interno della famiglia. Neodemos, Accessed on September 12, 2015, Available from: http://www.neodemos.info/il tempo denaro unanalisi della produ zione e del consumo di tempo allinterno della famiglia/. 